Polymer Journal, Vol. 4, No. 1, pp 111-113 (1972)

SHORT COMMUNICATION

\title{
Thermal Stability of Hexamethylolmelamine
}

\author{
Thomas Rae MANLEY \\ Department of Materials Science, Newcastle upon Tyne Polytecnic, \\ Ellison Place, Newcastle upon Tyne, NE1 8ST, England. \\ (Received March 29, 1972)

\begin{abstract}
KEY WORDS Melamine-Formaldehyde / Differential Thermal Analysis (DTA) / High Temperature Degradation /
\end{abstract}

From thermogravimetry it has been deduced ${ }^{1}$ that hexamethylolmelamine (HMM) degrades below $290^{\circ} \mathrm{C}$. As melamine formaldehyde resins are stable up to $350^{\circ} \mathrm{C}^{2}$ it was felt that further work on HMM would be useful.

\section{EXPERIMENTAL}

Thermogravimetry was performed on a Stanton HT-SM thermobalance. Evolved gas detection (EGD) was measured using a simple ceramic DTA cell and a gas density or katharometer detector $^{3}$. Differential thermal analysis (DTA) results were obtained in a pressure cell.

The pressure cell is a nickel cylindrical block $46-\mathrm{mm}$ tall and $43-\mathrm{mm}$ diam, into the top of which are sunk 3 round bottomed holes, $12-\mathrm{mm}$ diam, $\times 12-\mathrm{mm}$ deep, thus providing for two samples and a reference material. A lid locating pin is mounted on the top of the block.

The lid is $19-\mathrm{mm}$ deep by $64-\mathrm{mm}$ diam with a circular recess $2 \frac{1}{2}-\mathrm{mm}$ deep, into which the sample holder fits tightly. The two parts are bolted together and an aluminium foil gasket used to give a pressure tight seal. Chromelalumel thermocouples $(28 \mathrm{s.w.g})$ in ceramic tube insulator are sealed into the lid with kaolinsodium silicate cement; the thermocouple bead being $1.5 \mathrm{~mm}$ from the bottom of the wells in order to follow reactions occurring after the specimens have melted. The thermocouple signal is amplified to give a deflection of $10 \mathrm{~mm}$ per degree. An Ether Transistrol programmer, controlled by a thermocouple in the base of the pressure cell, is used to drive a $\mathbf{5 0 0}$ watt heater. The hexamethylolmelamine was made by adding $8 \mathrm{~mol}$ of formalin (37\% soln) to $1 \mathrm{~mol}(126 \mathrm{~g})$ of melamine at $\mathrm{pH}$ 8.0. The mixture was heated at $70^{\circ} \mathrm{C}$ for $5 \mathrm{~min}$ after solution occurred and then cooled with solid carbon dioxide. After standing overnight, the hexamethylolmelamine was washed with methanol and dried in vacuo at $50^{\circ} \mathrm{C}$. Analysis showed that an average of 5.8 methylol groups were attached to each melamine ring. The same method, using $3 \mathrm{~mol}$ of formalin was used for Trimethylolmelamine (TMM).

\section{RESULTS}

When HMM was heated in air, $32.8 \%$ was lost between 70 and $240^{\circ} \mathrm{C}$ and $35.73 \%$ between 360 and $400^{\circ} \mathrm{C}$. Anderson, et al. ${ }^{1}$, found on a Stanton MF-L5 thermobalance that $9.5 \%$ of HMM was lost at $100^{\circ} \mathrm{C}$ (this was attributed to moisture), $47.2 \%$ between 115 and $290^{\circ} \mathrm{C}$ (water and formaldehyde were found) and $33.6 \%$ at $290-550^{\circ} \mathrm{C}$. It was stated that ${ }^{1}$ the weight loss between 115 and $290^{\circ} \mathrm{C}$ was "too high to be ascribed to condensation and/or demethylolation reactions only and we believe that some degradation is also taking place". Even the higher figure of $47.2 \%$ may be accounted for on the basis of condensation and demethylolation reactions only, if it is assumed that the HMM forms linear polymers with methylene bridging groups and that the unreacted (third) methylol groups are completely demethylolated.

The molecular weight of hexamethylolmelamine is 306 .

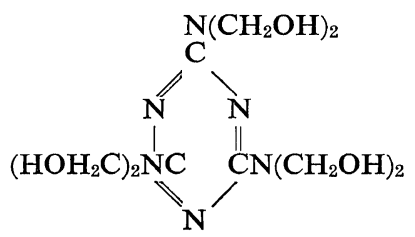


If this loses formaldehyde to give trimethylol melamine TMM, this would cause a loss of $90 \mathrm{~g} /$ mol. Condensation of TMM to give an ether bridge involves the loss of $1 \mathrm{~mol}$ of water, i.e., $9 \mathrm{~g}$ per triazine rings. The conversion of an ether to a methylene group involves the the loss of a mole of formaldehyde, i.e., $15 \mathrm{~g}$ per triazine ring. In a long-chain polymer two methylene bridges per triazine ring will be formed making a total loss of $48 \mathrm{~g}$ per ring, to which is to be added $30 \mathrm{~g}$ caused by the demethylolation of the third group. The total loss is therefore $90+48+30=168 \mathrm{~g}$ or $54.8 \%$. This percentage is smaller if shorter chains are involved. In the limiting case of an oligomer formed from two triazine rings only $24 \mathrm{~g}$ per ring are lost making $144 \mathrm{~g}$ in all or $47 \%$.

The rate of curing of HMM is very slow in the absence of catalyst and thus the weight losses obtained may be accounted for quite easily as being due to demethylolation reactions yielding the original amine groups and, in some cases, the entire melamine molecule which readily sublimes.

Further support for the view that the heating of HMM in an open atmosphere does not reproduce curing conditions was given by the results obtained in a Dean and Stark apparatus. When HMM is heated with toluene, formaldehyde is produced continuously together with a small amount of matter. The residue is a friable solid. When dimethylformamide is added, the reactants go into solution and the amount of water produced increases by an order of magnitude. The residue in this case is a hard cured resin. Similar results are obtained with TMM.

A properly cured melamine formaldehyde resin does not show any rapid loss of weight below $360^{\circ} \mathrm{C}^{2}$ unless an organic filler such as cellulose is used. This loss of weight was shown to be characteristic of melamine resins and was provisionally ascribed to degradation of the triazine ring. However, infrared measurements on specimens heated to $400^{\circ} \mathrm{C}$ still showed absorption due to the triazine ring at 815 and $840 \mathrm{~cm}^{-1}$ so that this hypothesis had to be abandoned.

\section{DIFFERENTIAL THERMAL ANALYSIS}

Apart from curing reactions nothing appears on the DTA trace before the exotherm that is found with all melamine formaldehyde compounds at around $360^{\circ} \mathrm{C}$. The exotherm is found with hexamethylol melamine, trimethylol melamine, melamine formaldehyde (MF) resins and melamine formaldehyde resins copolymerized with phenol. On the other hand, it is not found with pure melamine (althogh there was some evidence of a slight exotherm in some runs), with a melamine sulphate, with phenolic resins alone, nor with mixtures of the latter and pure melamine. It is known ${ }^{4}$ that ammonia is given off when the melamine is heated to around $360^{\circ} \mathrm{C}$. It is postulated, therefore, that pure melamine melts and then reacts giving off ammonia. The melting endotherm obscures the exothermic reaction.

Fully cured HMM, TMM, and MF resins are characterised by the fact that they contain the $\mathrm{RCNHCH}_{2} \mathrm{NHCR}$ linkage. The exotherm is therefore attributed to the breakdown of this linkage. As no reaction is obtained from phenolic resins it seems unlikely that methylol groups are involved.

\section{EGD/DTA RESULTS}

Two peaks are shown by the katharometer detector after the exotherm at $370^{\circ} \mathrm{C}$; on the gas density balance one of these is seen to be heavier and one lighter than argon-there is also a distinct amine smell. The lighter gas is taken to be ammonia and the heavier a methylamine. HMM that had been cured at $200^{\circ} \mathrm{C}$ was pyrolysed at $400^{\circ} \mathrm{C}$. The products gave a positive test for a primary amine with chloroform and $\mathrm{KOH}$.

\section{CONCLUSION}

Thermoanalytical investigations of methylol melamines performed at atmospheric pressure require to be interpreted with caution as the loss of formaldehyde and the sublimation of melamine may lead to erroneous conclusions.

Reports of degradation in cured HMM below $290^{\circ} \mathrm{C}$ have not been substantiated. No serious degradation occurs below $370^{\circ} \mathrm{C}$. At this point side chain groups break down but the triazine ring is not affected. 
Thermal Stability of Hexamethylolmelamine

\section{REFERENCES}

1. I. H. Anderson, J. A. C. Martin, and W. Steedman, "Chemistry and Industry", Society of Chemical Industry, London, 1968, p 1730.
2. T. R. Manley, Transactions of Plastics Institute, London, 1967, p 525.

3. D. A. Higgs and T. R. Manley, J. Appl. Polym. Sci., in press.

4. H. May, J. Appl. Chem., 9, 340 (1959). 